\title{
PMBOK® GUIDE: ÚJ SZERKEZETBEN A PROJEKTMENEDZSMENT TUDÁSANYAGA
}

A Guide to the Project Management Body of Knowledge (PMBOK® Guide) - Seventh Edition,

Newtown Square: Project Management Institute (PMI), 2021. $368 p$.

(ISBN-10: 1628256648, ISBN-13: 978-1628256642)

\begin{abstract}
$\mathrm{A}$ $P M B O K{ }^{\circledR}$ Guide megkerülhetetlen referenciamü a projektmenedzsment területén, olyan teljességre törekvő, rendszert adó kézikönyv, amely nem hiányozhat egyetlen projektvezető könyvespolcáról sem. Számos projektmenedzsment tárgyú minősítő vizsga alapvető szakirodalmi forrása szerte a világon. Fejlődéstörténete több mint harminc évre tekint vissza. Az előző kiadásokhoz hasonlóan a hetedik kiadás is a projektmenedzserek világszervezete, a Project Management Institute (PMI) gondozásában jelent meg. Szigorúan szabályozott közösségi alkotási folyamat keretében készült, különböző földrajzi régiókat és iparágakat képviselő nagyszámú szakember önkéntes közremüködésével. Az angol kiadást rendszerint számos nyelvre lefordítják. Három korábbi kiadás magyar fordításban is megjelent az Akadémiai Kiadó gondozásában.
\end{abstract}

A korábbi kiadások a projektmenedzsment átfogó folyamatmodelljére épültek, amelyet minden alkalommal továbbfejlesztettek. A 2017-ben megjelent hatodik kiadás az egyes (single) projekt menedzsmentjének szerteágazó tevékenységeit már 49 egymáshoz kapcsolódó folyamattal írta le. A könyv minden kiadással egyre terjedelmesebbé vált, a 756 oldalasra növekedett előző kiadás papíralapú formában már nehezen volt kezelhető.

A hetedik kiadás alkotói vélhetően rájöttek arra, hogy az egyébként rendkívül értékes folyamatmodell további finomítása már kevés hozzáadott értéket hozna. Ehelyett gondoltak egyet, és írtak egy teljesen új könyvet. Ezt a drámai fordulatot legalább ennyire indokolta az is, hogy a folyamatmodell jobbára a klasszikus vízesésmodellre épülő prediktív projektmenedzsment szemléletét tükrözi, hiszen születésekor jobbára nem is volt más. Az utolsó hatodik kiadásba igyekeztek ugyan minél többet becsempészni a kisebb lépésekre épülő, innovatív jellegü adaptív (agilis) megközelítésből, amelynek alkalmazása egyre inkább teret nyer napjainkban, de ez csak korlátozottan sikerült. Ezt a hátrányt a PMI úgy igyekezett kompenzálni, hogy a hatodik kiadást letöltő PMI tagok egyszerre, egy állományban egyesítve megkapták a $P M B O K{ }^{\circledR}$ Guide mellé rögtön az Agile Practice Guide (PMI, 2017) címü könyvet is, anélkül, hogy ezt kérniük kellett volna. A két könyv együtt tudta ugyanis lefedni az aktuális igényeket (másrészt így az agilis kiadvány is jobban terjedt). Sokan tévesen egy könyvnek is tekintették a kettőt.
A hetedik kiadás úgy kezeli ezt a problémát, hogy megemeli az absztrakciós szintet. Nem folyamatokról beszél, hanem alapelvekröl és teljesítményterületekröl. Ezzel egy olyan ernyőt képez, amely alá befér a prediktív és az adaptív (agilis) megközelítés, valamint a kettőt kombináló hibrid megközelítés is. Ez a megoldás egyik megközelítést sem részesíti előnyben a többivel szemben. Fontos kiemelni, hogy a hetedik kiadás nem váltja fel a folyamatmodellt részletező hatodik kiadást. Ez nem vált túlhaladottá, hanem továbbra is érvényes marad (mint ahogyan a már említett Agile Practice Guide is), hiszen egy fontos és hasznos megközelítést fejt ki. Egyébként szívesen vennénk egy, a hibrid megközelítést részletező PMI alapművet is, de az még várat magára.

A $P M B O K ®$ Guide korábbi kiadásai a projektmenedzsment amerikai szabványával együtt jelentek meg. A folyamatokat és ezek kapcsolódásait mindig a szabvány rögzítette, a Guide pedig ismét végigmenve ezen folyamatokon, kiegészítette ezeket a releváns eszközökkel és módszerekkel, és útmutatást adott megvalósításukhoz. Az új kötetben a 67 oldalas szabvány a könyv elejére került (ANSI-PMI/99-001-2021). Az előző kiadások folyamatorientált szabványai helyett most egy elv alapú szabványnyal van dolgunk, amely teljesen új szerkezetben és tartalommal jelent meg. A projekt sikeres lebonyolítását és az értékteremtést helyezi a középpontba, az értéket hordozó eredményre fókuszál. Az értékteremtő rendszer (system for value delivery) fogalmából indul ki, amely magába foglalja a szervezetet szolgáló stratégiai jelentőségü üzleti tevékenységeket, projekteket, programokat, portfóliókat és termékeket. A szabvány nyolc olyan funkciót nevez meg, amelyeket a projektek megvalósítanak, kitér továbbá a projektmegvalósítás és értékteremtés folyamatát befolyásoló külső és belső tényezőkre is.

A szabvány fö része a projektmenedzsment tizenkét alapelvét ismerteti, kiemelve, hogy ezek összhangban állnak a PMI etikai és szakmai magatartási kódexében kifejtett négy morális értékkel, amelyek a felelősségvállalás (responsibility), a tiszteletadás (respect), a tisztességesség (fairness), és az öszinteség (honesty). A tömören összefoglalt alapelvek az alábbi területeket érintik: gazdaszemlélet (a jó gazda felelösségvállalása); csapatépítés; projektérintettek bevonása; értékfókusz; rendszemléletü holisztikus gondolkodás; vezetői szerep; a kontextusnak megfelelően testreszabott müködés; átfogó minőségmenedzsment; a komplexitás, valamint a lehetöségek és fenyegetések kezelése; alkalmazkodóképesség és rugalmas ellenálló képesség; a cél eléréséhez szükséges változtatások keresztülvitele. Minden elv ismertetése egységes szerkezetben, táblázatos összefoglalással kezdődik, majd 
a kapcsolódó főbb fogalmak, megállapítások és ajánlások, illetve a megvalósítás rövid leírása következik, általában mindössze három oldalon.

A szabvány után következő tulajdonképpeni $P M B O K{ }^{\circledR}$ Guide három részből áll. Az első a projektmenedzsment teljesítményterületeket tekinti át, a második a testreszabás kérdéseivel foglalkozik, a harmadik pedig a projektmenedzsment gyakorlatában használatos konkrét modelleket, módszereket, eszközöket és dokumentumokat (artifacts) ismerteti. A nyolc teljesítményterület bizonyos fokig az előző kiadásban kifejtett tíz tudásterület utódjaként is értelmezhető. Az egyes teljesítményterületeken felmerülő tevékenységek a szervezeti környezet, a projekt jellege és célja, a projektérintettek, és egyéb tényezők által befolyásolt módon, párhuzamosan végzendők a projekt lefolyása során. A teljesítményterületek a következő témákhoz kapcsolódnak: projektérintettek; projektcsapat; fejlesztési megközelítés és életciklusmodell; tervezés; projektmegvalósítás és projektfolyamatok; projektterjedelem és minőség; értékelés; bizonytalanságok és kockázatok. Minden teljesítményterület bemutatása egy összefoglaló táblázattal indul, amit a főbb fogalmak, tevékenységek és más teljesítményterülettel kapcsolatos kölcsönhatások rövid leírása követ, és végül az elvárt eredmények hasznos ellenőrzőlistája zár le.

Érdemes kiemelni a testreszabással foglalkozó fejezetet. Ez a téma a korábbi kiadásokban eddig még nem kapott ekkora súlyt. Itt egyebek mellett a projektéletciklus és a fejlesztési megközelítés, a projektfolyamatok, a projektérintett-bevonás, továbbá a módszerek és dokumentumok, valamint a teljesítményterületek testreszabásáról olvashatunk.

Az azonnali gyakorlati alkalmazás számára adhat ötleteket az utolsó fejezet, amely a modelleket, módszereket és eszközöket tekinti át. A modell fogalmát meglehetősen tágan értelmezve 22 modellt mutat be nagyon röviden ( $\mathrm{pl}$. OSCAR, Tuckman Ladder). Ezt követi 60 módszer, valamint 76 eszköz (artifacts) egy-két mondatos leírása. Az utóbbiak túlnyomó többsége dokumentum. Az áttekintést segítik a modellek, a módszerek és az eszközök táblázatos összefoglalásai, amelyek kereszthivatkozásokkal jelzik ezek alkalmazhatóságát az egyes teljesítményterületeken. A fejezet rendszerező áttekintést ad, az egyes modellek, módszerek és eszközök mélyebb megismerésére azonban más forrásokat kell igénybe venni. Segíthet abban, hogy az olvasó kiválassza az alkalmazható módszertani elemeket, amelyeknek aztán máshol utána nézhet. A kötetet számos függelék, és a megszokott, igen hasznos, terjedelmes glosszárium zárja le. Irodalomjegyzéket nem tartalmaz. Ez érthető úgy is, hogy nem tudományos mü, de úgy is, hogy érvényességét nem a szakirodalommal, hanem a közösségi alkotási folyamattal igyekszik megalapozni.

Összefoglalva elmondható, hogy az új kiadás egy könnyebben áttekinthető teljesen új könyv lett, amely a projektmenedzsment kérdéseit kisebb terjedelemben és magasabb absztrakciós szinten tekinti át. Ez a megoldás jobb lehetőséget ad a különböző megközelítések egységes kezelésére, kevés specifikus utalást találunk azonban a prediktív, adaptív, vagy hibrid projektekre. A kötetet továbbra is világos felépítés és fogalomhasználat jellemzi. A korábbi kiadások olvasói szemében viszont kevésbé tartalmasnak, sőt, akár felszínesnek is tünhet. Hiányolhatják azt is, hogy a teljesítményterületeknél nem találhatók kereszthivatkozások a hatodik kiadásban tárgyalt tudásterületekre és folyamatokra. Megszünt a szabvány és az útmutató közötti korábbi erős közvetlen tartalmi kapcsolat. Felmerül a kérdés, hogy a szabványban miért éppen ezek az elvek szerepelnek. Az elvek egyébként keveset mondanak a kezdő szakemberek számára, ha nem tudnak mögéjük ismeretet, tapasztalatot, konkrétumot rendelni.

A $P M B O K ®$ Guide jellegét tekintve nem változott, elsősorban enciklopédikus jellegű, rendszert adó kézikönyv, és kevésbé bevezető jellegü tankönyv. Felépítése nem a kezdők világmodelljéhez igazodik. Számukra elsőként leginkább a projektmenedzsment teljesítményterületekkel foglalkozó fejezetek tanulmányozása ajánlható (vagy még inkább egy olyan egyszerübb tankönyv, amely a prediktív és/vagy az adaptív projektek tipikus életciklusába ad bevezetést). A kötetben terjedelmi okokból nem tárgyalt további részletek megismeréséhez más forrásokhoz kell nyúlni. Ebben segíthetnek a PMI további kiadványai, valamint a könyvhöz kapcsolódó online rendszer, a PMIstandards + Digital Online Platform feltöltés alatt álló tudásanyaga a szervezet honlapján, amely a gyakorlatban közvetlenül alkalmazható számos tanácsot, praktikus módszert és eszközt tartalmaz. 